DOI https://doi.org/10.30525/978-9934-26-111-4-14

\title{
ДО ПИТАННЯ ЕКОЛОГІЧНОГО БАЛАНСУ ЦИНКУ У ГРУНТАХ УКРАЇНИ
}

\author{
Єгорова Т. М. \\ доктор сільськогосподарських наук, \\ завідувачка лабораторї гідроекологї \\ Інститут агроекології і природокористування Наџіональної академії \\ аграрних наук Украӥни \\ Нагорнюк О. М. \\ кандидат сільськогосподарських наук, \\ старший науковий співробітник сектору навчальне - методичного та \\ інформачійного забезпечення \\ Інститут агроекології і природокористування Національної академії \\ аграрних наук Украӥни \\ м. Київ, Україна
}

Екологічні класифікації хімічних елементів узагальнюють особливості їх впливу на біологічні об'єкти різного ступеня організації. Екологічна геохімія розрізняє елементи есенційні, або життєво необхідні живим організмам, та неесенційні, що не є необхідними або досліджені недостатньо [1, с. 61]. Есенційні елементи у складі мікродобрив широко застосовуються для агрохімічного живлення грунтів, у складі харчових добавок - для годівлі худоби та риб, у медичних препаратах - як біорегулятори фізіологічних процесів людини. Як дефіцит (нестача), так і надлишок (надмір) цих елементів $\epsilon$ шкідливим для живого організму. Оцінками збалансованості елементів у рослинах та грунтах $\epsilon$ порогові біогеохімічні концентрації, які частково були визначені при широкомасштабних екологічних i геохімічних дослідженнях, що сформували наприкінці минулого століття низку новітніх екологічних напрямів [2, с. 9]. Есенційність цинку для рослинних організмів зумовлює біохімія процесів білкового, вуглеводневого та жирового обміну, для тварин - кровотворення i дихання. Цинк вважають базовим мікроелементом людського організму, який володіс протизапальними, противірусними, антиоксидантними й імуномодуляторними ефектами; він входить до складу близько 2000 ферментів, є необхідним для синтезу ДНК, а 
також для росту і розвитку клітин [3, с. 16]. Порогові біогеохімічні концентрації цинку в умовах нормального гомеостазу біологічних об'єктів становлять, за В.В. Ковальським, у грунтах - 30-70 мг/кг, у золі рослин - 20-500 мг/кг [1, с. 29]. Паталогічність цинку, за В.В. Івановим, вимірюється 16 ендемічними захворюваннями, які здатні формуватися у людей та худоби при його надлишку або нестачі у організмі.

Наші еколого-геохімічні дослідження засвідчили, що наприкінці 90-х років минулого сторіччя середні значення вміст цинку у грунтах адміністративних областей України становили 54-164 мг/кг. Надлишкові рівні цинку характеризували від 80 до100\% грунтів Закарпатської, Донецької, Луганської, Кіровоградської, Миколаївської областей. Результати міжнародних досліджень грунтів Європи 2008-2010 pp. [4, с. 467 ] підтвердили, що вміст цинку у грунтах цих територій досягає найвищих значень для України, що становлять 70-127 мг/кг (рис. 1).

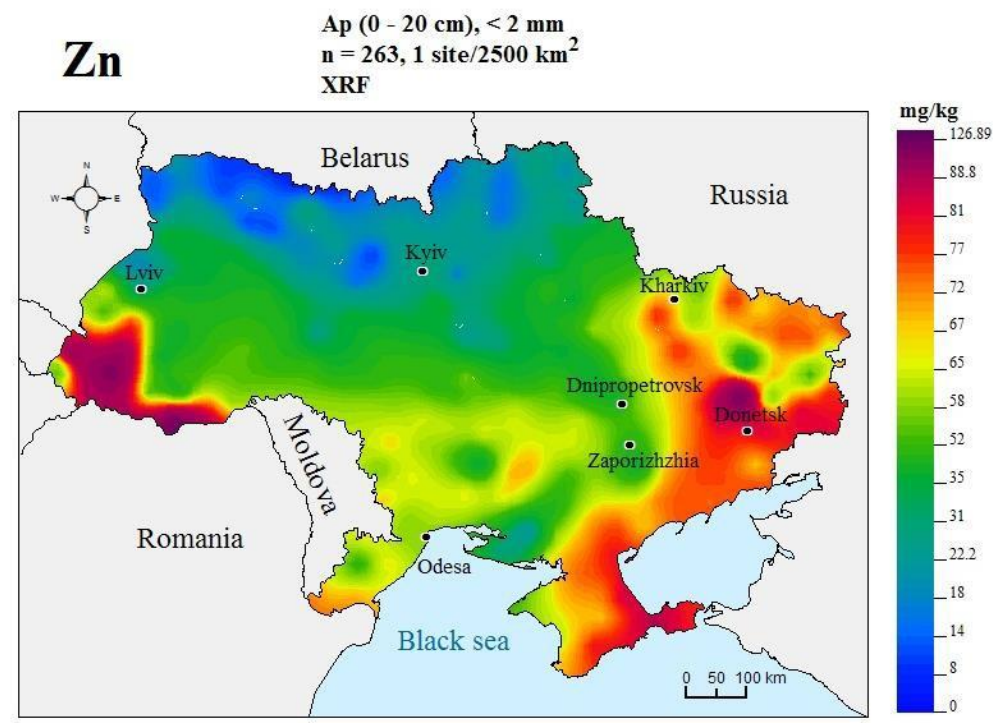

Рис. 1. Вміст цинку у орних грунтах України [5, с. 63]

Надлишковий дисбаланс цинку у грунтах порушує нормальне харчування рослин, що призводить до дрібнолисту або розеткової хвороби плодових культур, яка широко розповсюджена у Кримській, 
Херсонській, та інших південних областях України, вражаючи яблуню, грушу, вишню, черешню, сливу, персик, абрикос та інші дерева. Надлишок цинку в організмі людини, за О.П. Авциним, може призводити до специфічних форм отруєння, анеміям, дерматитам, депресії в поведінці, захворюванням крові та пригніченню окисних процесів всіх рівнів [6, с. 95]. Водночас, за умов пандемії короновірусної хвороби (COVID-19), роль цинку в біохімічних процесах людського організму набула додаткового обговорення з боку медиків $\mathrm{i}$ вірусологів. За узагальненнями І.В. Петренко, є всі підстави вважати цинк дієвим елементом профілактики та лікування коронавірусної інфекції, спричиненої вірусом SARS-CoV-2. Клінічні дослідження виявили, що цей есенційний мікроелемент бере участь у регуляції механізмів противірусного захисту та здатен пригнічувати самовідновлення SARS-CoV-2, тому додаткове вживання цинку вважають корисним доповненням до лікування пацієнтів із COVID-19 [3, с. 17].

Відкрита на сьогодні медична статистика захворюваності населення України на короновірусної хворобу [7] дозволяе отримати попередні оцінки про позитивну просторову узгодженість між надлишковим вмістом цинку у грунтах України та зниженими рівнями ураженості населення цим вірусом. За характером епідеміологічної ситуації у 24 областях України на 15.01.2021, середня кількість хворих на COVID -19 становила 42 745, а кількість померлих - 766 людей. Порівняно із цими середніми оцінками, у межах виділених нами областей України із суттєвим переважанням надлишку цинку у грунтах, кількість людей у Закарпатській, Луганській, Кіровоградській, Миколаївській областях, що захворіла на COVID-19 становило у 1,2-4,6 раз менше, а померлих від COVID-19 - у 1,1-1,5 разів менше.

Проведені дослідження дозволяють окреслити нові еколого-геохімічні і медико-екологічні напрями для удосконалення профілактики як короновірусної хворобі, так і певних ендемічних захворювань населення, худоби, або сільськогосподарських культур України, пов'язаних з дисбалансом цинку у грунтах України.

\section{Література:}

1. Сгорова Т.М. Екологічна геохімія агроландшафтів України: монографія / за наук. ред. О.І. Фурдичка. Київ: ДІА. 2018. 264 с.

2. Ковальський В.В. Геохимическая среда, микроэлементы, реакции организмов. Труды биогеохимической лаборатории Института геохимии и аналит. хим. им. В.И. Вернадского. 1991. Т. 22. С. 5-23. 
3. Цинк i COVID 19: що відомо на початок 2021року? Інтернетpecypc: https://health-ua.com/article/63510-tcink-COVID19-sho-vdomonapochatok-2021roku

4. Chemistry of Europe's Agricaltural Soils (2014) / L. Reimann, M. Birke, A. Demetriades, R. Filzmoser, P. O`Conner. Hannower: BGR. Part A. 528 p.

5. Геохімічний атлас грунтів України: масштаб $1: 5000 \quad 000$ (за результатами міжнародного проекту GEMAS) /B.P. Клос та ін. Київ: ДП «Українська геологічна компанія». 2015. 94 с.

6. Авцын А.П., Жаворонков А.А., Риш М.А., Строчкова Л.С. Микроэлементозы человека: этиология, классификация, органопатология. Москва: Медицина, 1991. 496 с.]

7. Короновірусна хвороба 2019 року в Україні. Інтернет-ресурс: https://uk.wikipedia.org/wiki/Коронавірусна_хвороба_2019_в_Україні

DOI https://doi.org/10.30525/978-9934-26-111-4-15

\title{
ECOLOGICAL COMPONENT OF ADVENTIVE ELEMENT OF KHARKIV URBAN FLORA (UKRAINE)
}

\author{
Zviahintseva K. O. \\ PhD, Assistant Professor, \\ Department of Botany and Plant Ecology \\ V. N. Karazin Kharkiv National University \\ Kazarinova H. O. \\ PhD, Assistant Professor, \\ Department of Botany and Plant Ecology \\ V. N. Karazin Kharkiv National University \\ Kharkiv, Ukraine
}

Adventive plant species cause changes in all structures of urban flora, including ecological. The expansion of the range of habitats and the strengthening of the role of adventive plants in the structure of plant communities indicates an increaseofinvasive potential of introduced species over the years.

The ecological analysis of adventive fraction of Kharkiv urban flora was processed using the classifications of R. Wittig et al. (degree of 66 